DOI: https://doi.org/10.24127/ajpm.v10i4.4335

\title{
PENGARUH PERAN ORANG TUA TERHADAP MINAT DAN HASIL BELAJAR MATEMATIKA
}

\author{
Maria Goretty D. Bantas ${ }^{1 *}$, Yasinta Yenita Dhiki ${ }^{2}$, Stefanus Notan Tupen $^{3}$ \\ ${ }^{1 *}, 2$ Pendidikan Matematika, Universitas Flores \\ ${ }^{3}$ Manajemen, Universitas Flores \\ *Corresponding author. \\ E-mail: $\quad$ bantasertyn@gmail.com ${ }^{*}$
}

Received 18 October 2021; Received in revised form 17 November 2021; Accepted 21 December 2021

\begin{abstract}
Abstrak
Tujuan Penelitian ini adalah untuk melihat peran serta dari orang tua dalam meningkatkan minat belajar anak untuk mata pelajaran matematika yang berpengaruh terhadap hasil belajar matematika anak setelah masa pandemic berakhir. Penelitian yang digunakan merupakan deskriptif kualitatif, yang menjadi subjek dlaam penelitian ini adalah peserta didik/I SMP yang bertempat tinggal di wilayah RT. 003, RW. 003 Kelurahan Tetandara Kabupaten Ende dengan jumlah 17 orang yang terdiri dari 9 peserta didik dan 8 siswi dengan sekolah yang berbeda dan orang tua yang berbeda. Hasil penelitian menunjukkan peran yang diberikan orang tua dalam proses pembelajaran matematika berupa memberikan bimbingan dan arahan, memberikan nasihat, mengawasi proses belajar, dan memenuhi fasilitas anak sebagai peserta didik dapat menumbuhkan minat anak yang dlihat dari perasaan senang, perhatian, ketertarikan dan keterlibatan anak dalam proses pembelajaran matematika yang dilaksanakan secara online.
\end{abstract}

Kata kunci: Pembelajaran matematika; peran orang tua; minat belajar.

\begin{abstract}
The purpose of this study was to see the role of parents in increasing children's interest in learning mathematics which affects children's mathematics learning outcomes after the pandemic period ended. The research used is descriptive qualitative, the subjects of this research are junior high school students who live in the RT area. 003, RW. 003 Tetandara Village, Ende Regency with a total of 17 people consisting of 9 students and 8 students from different schools and different parents. The results showed that the role given by parents in the mathematics learning process in the form of providing guidance and direction, providing advice, supervising the learning process, and fulfilling children's facilities as students can foster children's interest which can be seen from feelings of pleasure, attention, interest and involvement of children in the process. mathematics learning carried out online.
\end{abstract}

Keywords: Learning mathematics; role of parents; interest in learning.

This is an open access article under the Creative Commons Attribution 4.0 International License

\section{PENDAHULUAN}

Pendidikan merupakan upaya untuk meningkatkan kualitas peserta didik setelah melalui usaha belajar untuk memperoleh tujuan tertentu. Dalam dunia pendidikan, proses pembelajaran dapat menjadi sarana bagi peserta didik untuk mengembangkan kualitas diri sehingga tujuan dari pendidikan dapat tercapai. Akan tetapi, muncul suatu permasalahan, yaitu adanya pandemi covid 19. Kementerian Pendidikan dan Kebudayaan (Kemendikbud) memutuskan untuk memaksimalkan pemanfaatan teknologi untuk pembelajaran sebagai upaya untuk mengurangi mobilitas peserta didik (Aji, 2020). Kemendikbud memutuskan untuk melaksanakan pembelajaran tanpa tatap muka yang 
bertujuan untuk melindungi peserta didik serta mencegah penuran dan penyebaran vidur covid-19 (Kemendikbud, 2020).

Setelah dikeluarkannya himbauan serta perintah untuk melaksanakan pembelajaran secara daring melalui media-media online. Pembelajaran online yang dilakukan memanfaatkan teknologi dimana bahan ajar, forum diskusi, penugasan, dan ujian semuanya dilakukan secara online tanpa tatap muka langsung antara guru dan peserta didik. Dengan berlakunya sistem pembelajaran daring, membawa dampak dalam proses pembelajaran matematika.

Terdapat kendala-kendala dalam proses pembelajaran secara daring khususnya pada proses pembelajaran matematika. Pada dasarnya, mata pembelajaran matematika merupakan mata pelajaran yang lebih efektif jika diberikan secara langsung atau secara tatap muka. Pembelajaran matematika secara daring menemui banyak kesulitas seperti minimnya interaksi antara peserta didik dan guru, muatan materi matematika yang banyak dan selalu berdampingan dengan rumus dan selalu menyulitkan peserta didik, serta objek kajian matematika yang abstrak sehingga sulit dipahami (Fauzy \& Nurfauziah, 2021). Semua kendalakendala tersebut bermuara pada turunnya minat belajar peserta didik.

Jika minat peserta didik untuk belajar menurun maka motivasi belajar pun akan ikut menurun dan turunnya motivasi belajar agar berpengaruh pada keseriusan peserta didik untuk mencapai tujuan pembelajaran atau prestasi belajar peserta didik akan menurun (Harahap et al., 2021). Faktor minat belajar memegang peranan penting dalam kaitannya dengan hasil belajar matematika peserta didik (Sumiyati, Amri, \& Sukayasa, 2017). Berdasarkan fakta di lapangan, masih banyak peserta didik yang enggan untuk mengikuti pembelajaran daring baik untuk memperhatikan maupun berdiskusi (Sumartini \& Fitri, 2021). Hal ini semakin menunjukkan bahwa minat belajar peserta didik rendah.

Melihat berbagai permasalahan pada pembelajaran daring, maka diperlukan suatu perlakuan dan kolaborasi yang baik antara pendidik dan orang tua yang mendampingi peserta didik di rumah. Pembelajaran matematika secara daring menuntut adanya peran yang besar dari orang tua untuk mendampingi peserta didik selama proses pembelajaran ((Andriana, AR, \& Yahya, 2021); (Safriana, Nasriadi, \& Rahamattullah, 2021); (Na'im \& Ahsani, 2021); (Mayyustita \& Aini, 2021) dan (Solikhah \& Pujiastuti, 2021)). Peran orang tua tersebut pastinya harus menekankan pada peningkatan minat belajar matematika peserta didik meski pembelajaran dilaksanakan secara daring ((Marbun, 2021); (Fane \& Sugito, 2019); dan (Satria, 2021)). Akan tetapi, situasi pandemi yang cukup tiba-tiba membaut orang tua juga perlu untuk melakukan usaha agar tetap bisa mendampingi anaknya sembari mengerjakan kewajiban lainnya.

Berdasarkan latar belakang yang telah disampaikan, terlihat bahwa perlu adanya analisis terkait peran orang tua dalam meningkatkan minat belajar peserta didik selama pembelajaran daring. Salah satu daerah di kabupaten Ende, yaitu Tetandara Selatan, juga melaksanakan pembelajaran daring selama pandemi. Oleh karena itu diperlukan pula suatu penelitian untuk melihat peran orang tua selama pembelajaran daring khususnya kaitannya dengan minat belajar peserta didik. Secara lebih khusus, penelitian 
DOI: https://doi.org/10.24127/ajpm.v10i4.4335

ini memiliki tujuan untuk mendeskripsikan peran orang tua dalam meningkatkan minat belajar anaknya (peserta didik) pada mata pelajaran matematika yang berpengaruh terhadap hasil belajar matematika peserta didik setelah masa pandemi berakhir

\section{METODE PENELITIAN}

Jenis penelitian yang dilaksanakan adalah penelitian deskriptif kualitatif yaitu penelitian yang bertujuan untuk memahami fenomena yang dialami oleh subjek penelitian dengan data yang dikumpulkan berupa kata-kata, gambar, dan bukan angka. Penyusunan penelitian menggunakan data lapangan atau penelitian lapangan (field research) yang dilakukan untuk menjelaskan berbagai persoalan yang berkaitan dengan permasalahan yang dikaji yaitu untuk melihat pengaru dari peran serta orang tua untuk menumbuhkan minat belajar matematika pada anak usia SMP selama masa pandemi.

Adapun subjek dalam penelitian ini adalah peserta didik/siswi SMP yang bertempat tinggal di wilayah RT. 003, RW. 003 Kelurahan Tetandara Kabupaten Ende. Jumlah dari subjek penlitian adalah 17 orang yang terdiri dari 9 peserta didik dan 8 siswi yang berasal dari sekolah yang berbeda dan orang tua yang berbeda.

Data penelitian diperoleh dari dua angket. Angket yang pertama, untuk melihat peran serta orang tua dalam menumbuhkan minat belajar matematika pada anak dan angket yang kedua untuk melihat minat belajar anak pada mata pelajaran matematika selama pembelajaran dilakukan secara online. Angket yang digunakan adalah angket yang terstruktur atau tertutup dimana peserta didik dan orang tua menjawab sejumlah pertanyaan yang diberikan. Angket disusun berdasarkan aturan penskoran seperti pada Tabel 1 .

Tabel 1. Skor untuk angket

\begin{tabular}{ccc}
\hline No & Pernyataan Positif & Skor \\
\hline 1. & Selalu (SL) & 4 \\
2. & Sering (SR) & 3 \\
3. & Kadang-kadang (KD) & 2 \\
4. & Tidak Pernah (TP) & 1
\end{tabular}

Sumber: (Widoyoko, 2015)

Skor akhir diperoleh dengan menggunakan rumus berikut.

Skor $=\frac{\text { Total Skor yang diperoleh }}{\text { Total Skor Maksimum }} \times 100 \%$

Setalah diperoleh skor, kemudian skor tersebut diinterpretasikan seperti kriteria pada Tabel 2.

Tabel 2. Kriteria untuk angket

\begin{tabular}{ccc}
\hline No & $\begin{array}{c}\text { Tingkat } \\
\text { Pencapaian Skor }\end{array}$ & Kriteria \\
\hline 1 & $76-100 \%$ & Sangat Tinggi \\
2 & $51-75 \%$ & Cukup \\
3 & $26-50 \%$ & Kurang \\
4 & $0-25 \%$ & Sangat Rendah \\
\hline
\end{tabular}

Analisis data yang digunakan adalah analisis model Miles and Huberman. Aktivitas dalam analisis data yaitu data reduction, data display, dan conclusion drawing/ verification setelah itu data akan dianalisis dan dicari rata-rata secara deskriptif kualitatif. Adapun langkah-angkah penelitian yang akan dilakukan dapat dilihat pada Gambar 1. 
DOI: https://doi.org/10.24127/ajpm.v10i4.4335

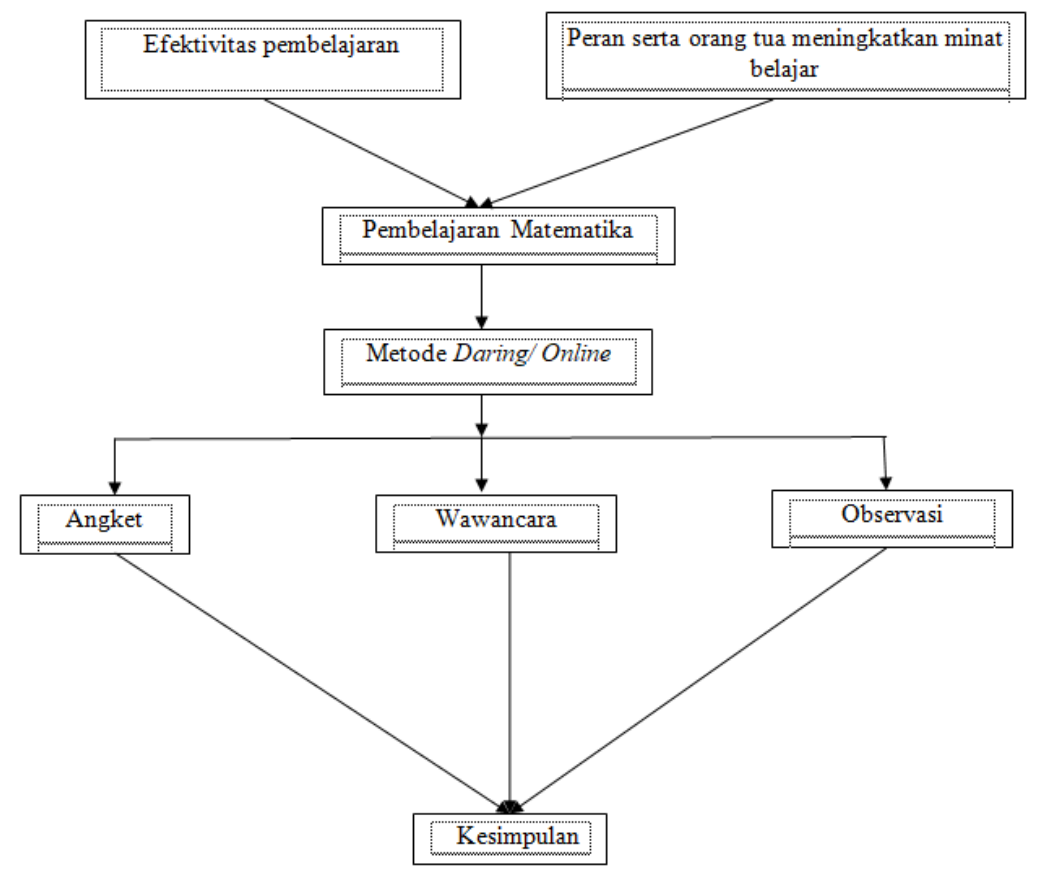

Gambar 1. Langkah-langkah penelitian

\section{HASIL DAN PEMBAHASAN}

Data hasil penelitian dibagi menjadi 2. Data hasil penelitian pertama adalah yaitu data hasil angket peran serta orang tua peserta didik SMP di kelurahan Tetandara RT.003 RW.003 yang berjumlah 17 orang. Sedangkan, untuk data hasil angket minat belajar anak (peserta didik) terhadap pembelajaran matematika yang dilaksanakan secara online yang diisi oleh peserta didik SMP yang orang tuanya telah mengisi angket peran orang tua.

Angket peran serta orang tua, terdiri dari 5 indikator yaitu: (1) Memberikan bimbingan dan arahan, (2) memberikan nasihat, (3) Mengawasi proses Belajar, (4) Memenuhi fasilitas anak, (5) Kurang perhatian terhadap kegiatan belajar anak. Untuk minat belajar anak pada angket kuesioner berisi 4 indikator yaitu (1) Perasaan senang, (2) Perhatian, (3) Ketertarikan, (4) Keterlibatan.

\section{Peran orang tua dalam menumbuhkan minat belajar matematika pada peserta didik SMP di kelurahan Tetandara}

Orang tua memiliki peranan dalam perkembangan aktivitas belajar anak dengan berlakunya system pembelajaran online yaitu menciptakan hubungan antara lingkungan keluarga dan lingkungan belajar dari anak sebagai peserta didik di lingkungan sekolah, salah satu contoh pada pembelajaran matematika. Orang tua harus mampu menciptakan suasana belajar yang menyenangkan bagi anak mengingat pelajaran matematika merupakan mata pelajaran yang sulit sehingga diperlukan suasana belajar yang menyenangkan bagi anak dan dapat mempengaruhi hasil belajar karena lingkungan keluarga memiliki peran penting bagi peningkatan mutu pendidikan anak dan dapat menumbuhkan minat belajar anak terhadap pembelajaran matematika 
DOI: https://doi.org/10.24127/ajpm.v10i4.4335

Masing-masing orang tua memiliki cara yang berbeda dalam menumbuhkan minat anak sebagai peserta didik untuk belajar matematika. Cara orang tua dalam menumbuhkan minat anak tersebut merupakan gambaran dari sikap dan perilaku orang tua dalam menumbuhkan minat anak untauk belajar matematika sehingga dengan proses pembelajaran matematika yang dialaksanakan secara online tidak membuat anak sebagai peserta didik merasa bosan dan malas mengikuti pelajaran melainkan sebaliknya anak semakin merasa tertantang untuk lebih giat belajar matematika.

Peran orang tua dalam menumbuhkan minat belajar anak sebagai peserta didik untuk proses pembelajaran matematika bagi anak atau peserta didik dapat berupa memberikan bimbingan dan nasihat agar anak dapat memahami bahwa orang tua juga terlibat aktif dalam proses pembelajaran matematika secara online, mengawasi kegiatan belajar peserta didik agar anak dapat lebih disiplin dalam mengikuti pembelajaran secara online, serta memenuhi fasilitas anak untuk pelaksanaan pembelajaran online agar anak semakin semangat untuk belajar matematika walaupun secara online sehingga tujuan belajar dapat terpenuhi dengan memanfaatkan fasilitas yang sudah disiapkan orang tua. Hasil rekap data dari angket peran serta orang tua dalam menumbuhkan minat belajar peserta didik SMP di kelurahan Tetandara dapat dilihat pada Gambar 1.

\section{PERAN ORANG TUA}

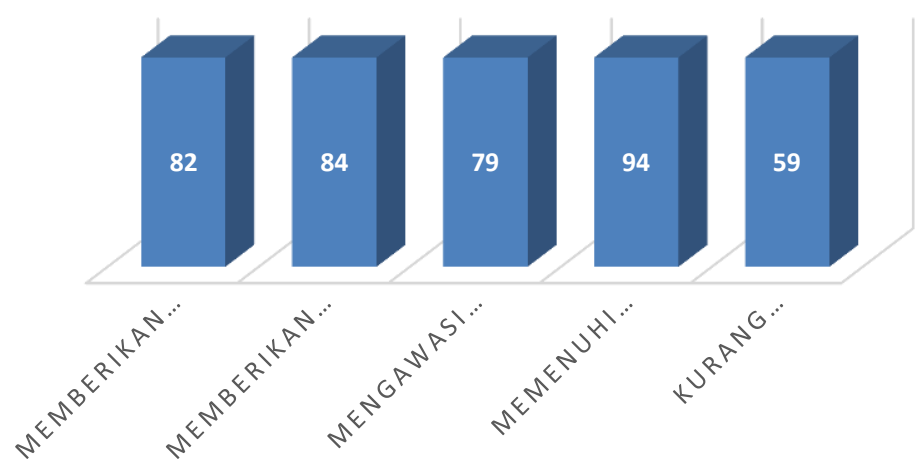

Gambar 1. Data hasil angket peran orang tua

Berdasarkan Gambar 1, hasil penelitian menunjukkan peran orang tua dalam memberikan bimbingan pada anak atau peserta didik pada saat pembelajaran matematika secara online berlangsung sebanyak $82 \%$ dengan total skors angket 56. Bimbingan yang diberikan seperti mendampingi dan menemani saat proses pembelajaran online berlangsung sehingga anak bisa mengikuti pelajaran matematika dengan tekun dan serius. $84 \%$ dengan total skor angket 57, menunjukkan bahwa orang tua memberikan nasihat atau arahan kepada anak atau peserta didik, nasihat yang diberikan tentang pentingnya memperkuat dasar-dasar matematika pada usia anak atau peserta didik dan untuk meransang minat anak atau peserta didik dalam bentuk memberikan 
hadiah atau reward saat anak mendapat nilai yang memuaskan dan memberikan sanksi atau punishment pada saat anak atau peserta didik tidak mengerjakan tugas atau memperoleh nilai yang kurang memuaskan baik dari nilai tugas maupun ulangan harian untuk mata pelajaran matematika. $79 \%$ dengan total skor angket 54, orang tua mengawasi proses pembelajaran matematika secara online yang diberikan seperti mengingatkan dan memantau tentang jadwal belajar online dan tugas-tugas yang harus dikerjakan anak agar nilai anak tuntas untuk mata pelajaran matematika. 94\% dengan total skor angket 64 , orang tua memenuhi fasilitas belajar anak dengan sangat baik. Fasilitas yang diberikan berupa handphone dan juga kuota internet. 59\% dengan total skor angket 40, orang tua terlihat kurang perhatian terhadap kegiatan belajar anak dikarenakan mereka sibuk dengan pekerjaan sehingga kurang berkomunikasi atau berinteraksi dengan anak untuk urusan sekolah dan mereka tidak paham dengan materi matematika sehingga mengalami kesulitan untuk membantu menjelaskan materi matematika. Berdasarkan hasil secara keseluruhan dari angket yang dibagikan kepada orang tua anak, diperoleh total jumlah skor angket 271 dan total skor maksimal
340. Peran serta orang tua dalam proses pembelajaran matematika kedalam presentase dapat diperoleh dengan rumus total skor secara keseluruhan dikali $100 \%$ dan dibagi total skor maksimal. Hasil perhitungan untuk presentase peran orang tua dalam proses pembelajaran matematika menunjukkan hasil 79,73\% dan menunjukkan kriteria peran orang tua "Sangat Tinggi".

\section{Minat belajar anak untuk mata pelajaran matematika secara online}

Data hasil minat belajar peserta didik diperoleh dari angket kuesioner yang diisi oleh peserta didik tanpa ada pengaruh dari orang lain. Kuesioner yang diisi terdiri dari 4 indikator minat belajar peserta didik yaitu perasaan senang, ketertarikan peserta didik, perhatian peserta didik, dan keterlibatan peserta didik. Responden dalam penelitian ini berjumlah 17 peserta didik yang terdiri dari 9 laki-laki dan 8 perempuan yang bertempat tinggal di RT/RW 003/003 kelurahan tetandara ,Ende Selatan Kabupaten Ende.

Hasil rekap data dari angket peran serta orang tua dalam menumbuhkan minat belajar peserta didik SMP di kelurahan Tetandara dapat dilihat pada Gambar 2.

\section{Data Hasil Angket Minat Peserta Didik}

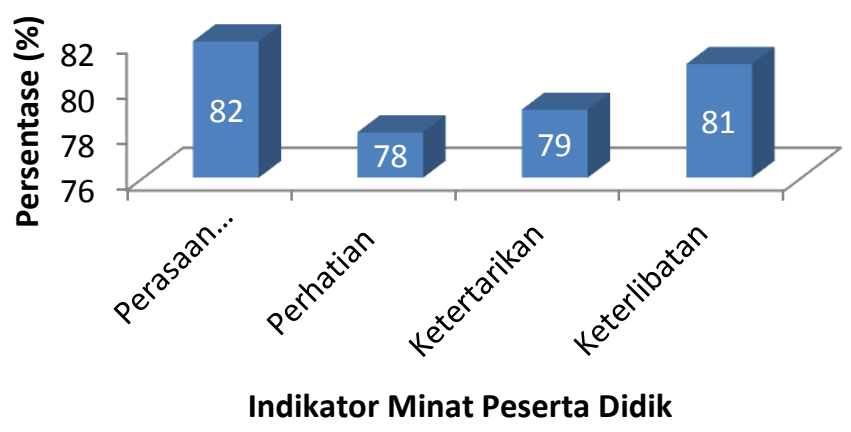

Gambar 2. Data hasil angket minat peserta didik 
DOI: https://doi.org/10.24127/ajpm.v10i4.4335

Berdasarkan Gambar 2, dapat dilihat untuk indikator perasaan senang terhadap pembelajaran matematika yang dilaksanakan secara online mencapai $82 \%$ dengan total skor angket 56. Berdasarkan angket yang berisi poinpoin (1) pendapat peserta didik tentang pembelajaran matematika secara online, (2) kesan peserta didik terhadap guru matematika, dan (3) perasaan peserta didik selama mengikuti pembelajaran matematika dengan presentase yang tinggi akan membuat minat peserta didik dalam mengikuti pembelajaran matematika juga menjadi tinggi. Hal ini sejalan dengan penelitian sebelumnya yang menyebutkan bahwa minat belajar adalah kecenderungan individu untuk memiliki rasa senang, dorongan untuk melakukan aktivitas dalam kegiatan pembelajaran yang dilakukan melalui latihan ataupun pengalaman (Handayani, 2016).

Untuk indikator perhatian peserta didik dengan poin-poin: (1) perhatian peserta didik saat mengikuti proses pembelajaran matematika secara online, (2) perhatian peserta didik saat proses diskusi berlangsung selama pembelajaran matematika dilaksanakan secara online, hasil penelitian menunjukkan $78 \%$ dengan total skor angket 53 dan hal ini menunjukkan bahwa minat belajar peserta didik dari indikator perhatian terhadap pembelajaran dapat digolongkan sangat baik karena hamper semua peserta didik memberikan perhatian selama proses pembelajaran online berlangsung. Perhatian peserta didik dalam kegiatan pembelajaran dipengaruhi oleh tingginya kemandirian peserta didik dan kemandirian peserta didik dalam pembelajaran sangat erat kaitannya dengan minat belajar. Hal ini sejalan dengan penelitian sebelumnya yang menyebutkan bahwa peningkatan minat berbanding lurun dengan peningkatan kemandirian belajar (Harahap et al., 2021).

Indikator ketertarikan memuat dua poin dalam pernyataan angket yaitu (1) memiliki rasa ingin tahu saat pelajaran matematika berlangsung, (2) bersikap menerima sat menerima tugas atau ulangan yang diberikan oleh guru pada saat pelajaran matematika berlangsung. Berdassarkan hasil penelitian, indikator ini memperoleh $79 \%$ dengan total skor angket 54 yang menunjukkan peserta didik yang merasa tertarik mengikuti pelajaran dengan persentase kategori Baik. Ketertarikan peserta didik mengikuti pelajaran mengindikasikan tingginya minat belajar peserta didik. hal ini sejalan dengan penelitian sebelumnya yang menyebutkan bahwa semakin besar perhatian orang tua ketika anaknya belajar serta diikuti minat belajar yang tinggi maka akan meningkatkan prestasi belajar anak (peserta didik) (Handayani, 2016).

Indikator keterlibatan peserta didik dalam pembelajaran matematika dengan poin (1) kesadaran pentingnya belajar matematika dari rumah dan poin (2) kegiatan peserta didik sebelum dan setelah masuk sekolah dari angket penelitian mencapai $81 \%$ dengan total skor 55 yang menunjukkan peserta didik yang memiliki ketertarikan pada pembelajaran matematika secara online atau dari rumah. Hal ini menunjukkan bahwa indikator ini masuk kategori baik, dimana dalam suatu pelajaran peserta didik yang memiliki minat terhadap satu mata pelajaran akan terlibat aktif dalam proses belajar mengajar walaupun prosesnya dialaksanakan dari rumah atau online. Hal ini sesuai dengan yang dikemukakan Slameto bahwa peserta didik yang menyadari matematika merupakan pelajaran yang penting 
untuk dipelajari maka kemungkinan besar peserta didik tersebut akan memiliki minat dan memotivasi diri untuk lebih giat berperan aktif dalam proses pembelajaran.

\section{KESIMPULAN DAN SARAN}

Dalam proses pembelajaran matematika secara online, diperlukan peran serta orang tua dalam meningkatkan minat belajar pada anak. Peran orang tua yang dapat ditunjukkan dalam meningkatkan minat belajar anak pada pembelajaran secara online yaitu (1) memberikan bimbingan dan arahan, (2) Memberikan nasihat, (3) mengawasi proses belajar, dan (4) memenuhi fasilitas anak. Keempat poin itu dapat mendukung proses belajar matematika yang dilaksanakan secara online. Peran serta yang diberikan orang tua dalam proses pembelajaran matematika secara online dapat meningkatkan minat anak yang dilihat dari perasaan senang anak saat mengikuti pembelajaran matematika, perhatian yang diberikan saat proses pembelajaran berlangsung, ketertarikan yang ditunjukkan anak pada saat mengikuti pelajaran matematika, dan keterlibatan aktif anak saat pembelajaran berlangsung.

Saran yang dapat diberikan sesuai hasil penelitian, bagi guru: memberikan pembelajaran yang menarik sehingga dapat membuat peserta didik lebih giat untuk belajar matematika walaupun pelkasanaannnya secara online. Bagi orang tua: selalu mendampingi dan memantau anak dalam proses belajar matematika dan memberikan fasilitas sesuai dengan kebutuhan anak untuk proses pembelajaran matematika sehingga dapat menumbuhkan minat anak untuk lebih giat belajar matematika. Bagi anak sebagai peserta didik: terus menumbuhkan minat belajar pada pembelajaran matematika sehingga dapat memperoleh hasil atau nilai yang memuaskan dalam pelajaran matematika.

\section{DAFTAR PUSTAKA}

Aji, R. H. S. (2020). Dampak Covid-19 pada Pendidikan di Indonesia: Sekolah, Keterampilan, dan Proses Pembelajaran. SALAM: Jurnal Sosial Dan Budaya Syar-I, 7(5), 395-402.

https://doi.org/10.15408/sjsbs.v7i5. 15314

Andriana, AR, R. A., \& Yahya, A. (2021). ANALISIS PERANAN ORANG TUA TERHADAP PRESTASI BELAJAR SISWA KELAS 8 MTS DDI TINIGI DALAM BIDANG MATEMATIKA. Elips: Jurnal Pendidikan Matematika, 2(2), 124-134.

Fane, A., \& Sugito, S. (2019). Pengaruh Keterlibatan Orang Tua, Perilaku Guru, dan Motivasi Belajar Terhadap Prestasi Belajar Matematika Siswa. Jurnal Riset Pendidikan Matematika, 6(1), 5361.

https://doi.org/10.21831/jrpm.v6i1. 15246

Fauzy, A., \& Nurfauziah, P. (2021). Kesulitan Pembelajaran Daring Matematika Pada Masa Pandemi COVID- 19 di SMP Muslimin Cililin. Jurnal Cendekia: Jurnal Pendidikan Matematika, 05(01), 551-561.

Handayani, S. (2016). Pengaruh Perhatian Orangtua Dan Minat Belajar. Jurnal Formatif, 6(2), 141-148. Retrieved from https://media.neliti.com/.../234830pengaruh-perhatian-orangtua-danminat-be-bb3ab.

Harahap, H. S., Hrp, N. A., Nasution, I. B., Harahap, A., Harahap, A., \& 
Harahap, A. (2021). Hubungan Motivasi Berprestasi, Minat dan Perhatian Orang Tua Terhadap Kemandirian Siswa. Edukatif: Jurnal Ilmu Pendidikan, 3(4), 1133-1143. Retrieved from https://edukatif.org/index.php/eduk atif/index

Kemendikbud. Pedoman Penyelenggaraan Belajar Dari Rumah Dalam Masa Darurat Penyebaran Corona Virus Disease (Covid-19). , Surat Edaran Nomor 15 Tahun $2 \mathrm{O} 2 \mathrm{O} \S(2020)$.

Marbun, Y. M. R. (2021). Pengaruh Perhatian orang Tua dan Motivasi Belajar Siswa Terhadap Hasil Belajar Matematika Siswa SMP. Jurnal Matematics Paedagogic, 5(2), 111-120.

Mayyustita, E. N., \& Aini, I. K. (2021). Peran Orang Tua dalam Pembelajaran Anak Kesulitan Belajar Dimasa Pandemi Covid-19. Jurnal Pendidikan Khusus, 16(2), $1-10$.

Na'im, Z., \& Ahsani, E. L. F. (2021). Peran Orang Tua Terhadap Hasil Belajar Siswa Pada Pembelajaran Daring. Pedagogika, 12(Nomor 1), 32-52.

https://doi.org/10.37411/pedagogik a.v12i1.621

Safriana, C., Nasriadi, A., \& Rahamattullah. (2021). Pengaruh motivasi Orang Tua Terhadap Prestasi Belajar Matematika Siswa Kelas VIII SMP Negeri 1 Alafan. Jurnal Ilmiah Mahasiswa, 2(1).

Satria, T. G. (2021). Hubungan Perhatian dari Orang Tua Terhadap Hasil Belajar Siswa Sekolah Dasar. Sekolah Dasar: Kajian Teori Dan Praktik Pendidikan, 30(1), 71-76.

Solikhah, L. F., \& Pujiastuti, H. (2021). Peran Orang Tua Dalam Meningkatkan Motivasi Belajar
Matematika Pada Masa Pandemi Covid-19. Jurnal Educatio, 7(3), 668-673.

https://doi.org/10.31949/educatio.v 7i3.1181

Sumartini, A., \& Fitri, A. (2021). Analisis Minat Belajar Siswa Kelas VIII SMP Negeri 2 Tulis Pada Pembelajaran Matematika Secara Daring. Konferensi Ilmiah Pendidikan Universitas Pekalongan, 179-186. Retrieved from

https://proceeding.unikal.ac.id/inde x.php/kip

Sumiyati, T., Amri, B., \& Sukayasa. (2017). Pengaruh Perhatian Orang Tua, Konsep Diri, dan Motivasi Belajar Terhadap Hasil Belajar Siswa Tentang Matematika Kelas VIII SMP Negeri Di Kecamatan Sausu Kabupaten Parigi Moutong. Jurnal Mitra Sains, 5(2), 84-94. 